\title{
Az óvodai ének-zenei nevelés módszertanának alakulása - Forrai Katalin módszertani könyveinek elemző bemutatása
}

\author{
Hegedüsné Tóth Zsuzsanna
}

Eötvös Loránd Tudományegyetem Tanitó- és Óvóképzö Kar Ének-zenei Tanszék

\begin{abstract}
Absztrakt
Forrai Katalin mint Kodály Zoltán-tanítvány fektette le Magyarországon a kora gyermekkori ének-zenei nevelés módszertanának alapjait. Ebben a tanulmányban tartalomelemzés módszerével kerül feltárásra, hogy tartalmi, módszertani szempontból hogyan formálódtak Forrai Katalin módszertani könyvei: az 1951-es Óvodai énektanitás, az 1957-es Ének-zene az óvodában és az 1974-es Ének az óvodában. Az eredmények ráirányítják a figyelmet arra, hogy az óvodáskorúak zenei nevelését jelentős változások formálták a tekintetben, hogy milyen zenei anyagra épüljön, hogyan szerveződjön a tevékenység vagy milyen fejlesztési területeket, milyen eszközökkel célozzon. A feltárt változások hozzásegítenek, hogy szem előtt tartsuk módszertani értékeinket és ezeket az értékeket megőrizve tudjon megújulni az óvodai zenei nevelés.
\end{abstract}

Kulcsszavak: ének- és zeneoktatás, módszertan, óvoda, tartalomelemzés

\section{Bevezetés}

Forrai Katalin a kora gyermekkori és óvodai zenei nevelés hazai és nemzetközi szinten elismert alakja. Ének-zenei nevelési koncepcióját az 1940-es évek végétől kezdte kidolgozni, és mintegy hatvan éven keresztül vállalt mind nagyobb szerepet a bölcsődés- és óvodás korúak zenei nevelésében. Az 1974ben első ízben kiadott Ének az óvodában, és az 1986-ban kiadott Ének a bölcsődében könyvei a mai napig alapvető fontosságúak. Forrai Katalin maga is hangoztatta, hogy a „kicsinyek” zenei nevelése Kodály útmutatása alapján vált közérdekü, tudományos feladattá.

A kodályi alapelveken nyugvó óvodai ének-zenei nevelési koncepcióját az 1964-es, Magyarországon megrendezett ISME (International Society for Music Education) konferenciát követően jelentős nemzetközi érdeklődés övezte, mivel ezen a rendezvényen Forrai Katalin élő zeneóvodai bemutatókat tartott 
három különböző életkorú óvodás csoporttal. 1968-ban már ki is adták japán nyelven az Ének-zene az óvodában könyvét, és a 80-as években az Ének az óvodában könyvét angol és japán nyelven is. Ezekhez a kiadásokhoz Forrai Katalin szakmai közremüködésével adaptált gyüjtemények is készültek.

Jelen tanulmány célja, hogy visszanyúljunk autentikus, eredeti forrásokhoz, megismerjük azt a kort, amiben kialakult az ő óvodások zenei neveléséhez kapcsolódó módszertani elképzelése, és lássuk, hogy hogyan ment át a folyamatos változáson. Az áttekintés megerősítést adhat arra, hogy Forrai Katalin zenepedagógiai koncepciója, annak alappillérei változatlanul egyetemes érvényüek, hitelesek és iránymutatóak.

\section{A kutatás motivációs háttere és célja}

Az óvodapedagógusok ének-zenei képzésének alapja Forrai Katalin Ének az óvodában könyve, mely 2020-ig 23 kiadást ért meg, és 1974 - az első megjelenése - óta alapjául szolgál az óvodások zenei nevelésének. Oktatóként, óvóképzős hallgatók ezen könyvön nyugvó módszertani felkészítése során fontosnak tartom a szemléltetést, a hídépítést az elméleti képzés és a gyakorlati képzés között. Arra törekszem, hogy a hallgatók már akkor lássák, hogyan valósul meg a módszertan a gyakorlatban, amikor még csak az elméletet tanítom nekik, sőt, már akkor, amikor az első népi énekes játékokat játsszuk a szemináriumokon. Ehhez részletekbe menően fel szerettem volna tárni Forrai Katalin módszertanát, és találni olyan videófelvételeket, amelyeken példaértékủ módszertani fogásokat láthatnak, jól bemutathatóak számukra a gyerekek életkorához illeszkedő, énekes-zenei fejlődésüket igényesen támogató játékos fejlesztő ötletek, amelyeken keresztül korszerü tevékenységszervezést ismerhetnek meg.

A Tanító- és Óvóképző Kar archív felvételei között találtam olyan felvételeket, ahol Forrai Katalin foglalkozott óvodásokkal. A felvételeket nézve világossá vált számomra, hogy Forrai Katalin foglalkozásvezetését napjaink képzésén is érdemes bemutatni, nemcsak azért, mert a leghitelesebben, legautentikusabban mutatja be az óvodáskorúak ének-zenei nevelésének módszertani alapjait, hanem azért, mert pedagógiai szempontból sem tekinthető elavultnak. Az általa vezetett foglalkozások a gyermekek életkori igényének megfelelően játékosak, kellően változatosak, lendületesek, kielégítik a gyermekek mozgásigényét. Forrai Katalin értékes módszertani fogásokat alkalmazva folyamatosan ébren tartja a gyermekek figyelmét, akik láthatóan motiváltan vesznek részt a közös tevékenységekben.

Napjaink pedagógiai tudása szerint valljuk, hogy a bevésődés, interiorizálódás alapja a belülről fakadó érdeklődés, a pozitív érzelmi viszonyulás, a játékosság, a közösségi élményt adó tevékenységbe ágyazott tanulás. Forrai Katalin foglalkozásainak elemzése során világosan látszik a kiemelt fejlesztési feladat, annak jól felépített, tudatos előkészítése, a csoportos és egyéni gyakoroltatás megvalósulása, az elsajátítás ellenőrzése, és az adaptív, személyre 
szabott javítás, korrigálás is. Közben nem ad alább a tiszta éneklés igényéből, a pontosan kiénekelt dallamból, az egyöntetü, egyenletes járásból, a lüktetéshez igazított játékos mozdulatokból, az esztétikusan kibontakozó játékfolyamatból. Ám miközben következetesen végigviszi a didaktikai feladatokat, a gyermekek életkori szükségletei is kielégítésre kerülnek.

Fontosnak tartom hitelesen átadni, bemutatni Forrai Katalin módszertani örökségét, amihez első lépés lehet közelebbről megismerni módszertani alapvetéseit, feltárni koncepciójának gyökereit. Ebben a tanulmányban először rövid pedagógiatörténeti kitekintést teszek, hogy bemutassam a magyar oktatás- és nevelésügyet, az óvodáztatás rendszerét, azt, hogy fejlődéslélektani szempontból hogyan tekintettek akkor az óvodáskorú gyermekekre, és hogyan alakult az óvodákban az ének-zenei koncepció. Ezt követően részletekbe menően bemutatom és összehasonlító tartalomelemzésnek vetem alá Forrai Katalin Ének az óvodában című (1974) könyvét, valamint az azt megelőző két módszertani könyvet, az 1951-es Énektanitás az óvodában és az 1957-es Ének-zene az óvodában címü könyveket.

Célom annak bemutatása, hogy milyen változásokon ment keresztül Forrai Katalin három módszertani könyve, hogyan nyerte el végső formáját módszertana, mennyire tudatosan válogatta össze a módszertanhoz kapcsolódóan a hároméves óvodai zenei anyagot, és nem utolsósorban, hogy középpontba állítsam őt magát, a példaértékű pedagógust.

\section{Történeti kitekintés: Óvodaügy, óvóképzés és Forrai Katalin pályájának indulása (1947-1974)}

1947-ben, mikor Forrai Katalin óvodai zenei nevelést érintő pályája elindult, Magyarországon már komoly múltja volt az óvodáztatásnak, sőt az óvóképzésnek is. A magyar állam fontosnak tartotta az óvoda intézményét, annak az iskolát előkészítő szerepét, sőt az óvók képzését, továbbképzését is. Már 1891-ben elfogadták az első óvodai törvényt, melynek nyomán komoly törekvések indultak az óvodai nevelés korszerübbé tételére, többek között e törvény szabályozta az óvónők képzését is. A 20. század 30-as éveiben igen erőteljes volt a német befolyás Magyarországon. Ennek ellensúlyozására kapott a nevelés-oktatás terén mind hangsúlyosabb szerepet a népi hagyományok őrzése, a nemzetté nevelés vezérgondolata. Kodály Zoltán, a korszak magyar és nemzetközi kulturális életének kiemelkedő, nagy tekintélyű alakja is ekkor adott hangot az óvodai zenei nevelésre vonatkozó elképzelésének - mégpedig az 1941-es Zene az óvodában című, nagy hatású előadásában, amely később tanulmányként is megjelent. A népi-nemzeti törekvések a háborús években nem tudtak kibontakozni, s a német megszállás (1944-1945), valamint az 1947-től megerősödo” „szovjetizálás” , hosszú évtizedekre meghatározták a magyar köznevelést, például az óvodák müködését. 1948-ban az óvodákat és az iskolákat államosították. A korábban szociálpolitikai intézménynek tekintett óvodák a Népjóléti Minisztérium felügyelete (1945-1949) alól a közoktatásügyi 
tárca hatáskörébe kerültek mint nevelési intézmények. 1953-ban új törvény született az óvodai nevelésről (1953. évi III. kisdedóvási törvény). Az óvodák bekerültek a közoktatás intézményei közé. Az óvodák iskolaelőkészítő funkciója ebben a koncepcióban megkérdőjelezhetetlen lett, és ez meghatározta az óvodai nevelőmunka szemléletmódját. Az óvodán belüli tanulás tulajdonképpen az iskolai tanulás adaptációja lett. Ugyanakkor ez a változás volt az, ami elősegítette az óvodapedagógia és az óvodapedagógusi pálya presztízsének erősödését és azt, hogy 1959-ben a középfokú óvónőképzés megszűnt, és az óvodapedagógus-képzés bekerült a felsőfokú képzések körébe.

Az európai országok között Magyarország óvodai hálózata, amely azt célozta, hogy teljeskörűvé váljon az óvodáztatás, egyedülálló volt. Forrai Katalinnak, Kodály Zoltán avatott tanítványának jó táptalaj volt ez ahhoz, hogy az óvodáskorúak zenei nevelését a kodályi elveken alapuló ének-zene módszertanával támogassa. Forrai Katalin az 1945-ben, Debrecenben megszerzett tanítói- és énekszaktanítói képesítéssel Budapesten 1947 és 1951 között elvégezte a Liszt Ferenc Zeneművészeti Főiskola középiskolai énektanári- és karvezetői szakát is. Ahogy visszaemlékezéseiből is olvashatjuk, már ekkor határozott elképzelése volt arról, hogy ő az óvodások zenei nevelésével kíván foglalkozni. 1947-ben mestere, Kodály Zoltán tanácsára kísérleti jelleggel elindította egy fővárosi, a VIII. kerületi Csobánc utcai óvodában „zeneóvodai” foglalkozásait (Bónis, 1979) azzal a céllal, hogy énekes foglalkozásainak hatását megfigyelhesse hátrányos sorsú, rossz anyagi körülmények között élő gyermekeken. Forrai Katalin zeneóvodai foglalkozásait mind nagyobb érdeklődés övezte a hazai és nemzetközi szakemberek körében. Azok, akik azért érkeztek Magyarországra, hogy betekintést nyerjenek a kodályi koncepción nyugvó ének-zenei nevelésbe, szinte kivétel nélkül ellátogattak ebbe a fővárosi óvodába. Kodály Zoltán egyébként haláláig, 1967-ig maga is figyelemmel kísérte Forrai Katalin itt folyó munkáját. Forrai Katalin országos elismertségét tovább növelte, hogy 1953tól a rádiótól érkezett felkérésre a Magyar Rádióban Óvodások műsora címen heti rendszerességgel zeneóvodai foglalkozásokat vezetett. (1985-ig, 32 éven keresztül sugározta a rádió foglalkozásait minden héten egyszer.) Közben, a Liszt Ferenc Zeneművészeti Főiskolán megszerzett diplomájával 1951-től tanítani kezdett a budapesti Brunszvik Teréz Óvónőképzőn egészen 1959-ig, a középfokú óvónőképzés megszűnéséig. Mindennapi gyakorlati tevékenysége - középiskolai oktatása, zeneóvodai tanítása - mellett Kodály Zoltán biztatására énekeskönyv szerkesztésébe kezdett és összeállította kollégáival, Barát Istvánnéval és Oláh Zsuzsannával 1951-ben a négy további kiadást is megérő Óvodai énektanítás címü módszertani könyvet, melyhez gyűjteményes részt is illesztettek. Ez a módszertani segédkönyv az 1953-as óvodai nevelést érintő törvény kapcsán országosan is ismertté vált, ugyanis a törvény azt szorgalmazta, hogy egységes legyen az óvodákban folyó munka. A könyv gyüjteményében mintegy 200 dalt rendeztek el nehézség szerint, az óvodások életkorához igazítottan. A dalok nagy része Kodály Zoltán népzenei gyüjtéséből került ki, azonban Forrai Katalinnak és kollégáinak lehetősége volt a kor legmeghatáro- 
zóbb, legsokrétúbb magyar népi gyermekdalokat tartalmazó Magyar Népzene Tára I., Gyermekjátékok kéziratából (Bartók \& Kodály, 1951) is válogatni. Forrai Katalin az Így láttuk Kodályt című emlékkötetben ezt írja: „már megvolt a Magyar Népzene Tára első kötetének, a Gyermekjátékoknak a nyomdai lenyomata. Az anyagot módom volt megtekinteni és azt hittem, bőven lesz benne alkalmas gyermekjáték az óvoda számára is. A Tanár Úr azonban sokféle követelményt állított, s ezek korlátozták a válogatás lehetőségét: a dalanyag pentaton dallamfordulatokon mozogjon, egyszerü legyen és formailag ép, a szövege világos, a kisgyermekhez közel álló. (Ide értette a humoros, abrakadabra szövegeket is.) Végül a játéka is feleljen meg a 3-6 éves gyerekeknek, ami azért volt nehéz feltétel, mert ezeket eredetileg nagy lányok játszották. Az 1200 dalból - ilyen szempontok szerint - 150-et válogattam ki néhány tanártársammal, abból Tanár Úr, egyenként megvizsgálva a dalokat, 45-öt hagyott jóvá." (Bónis, 1979, p. 205-206). Egy másik visszaemlékezése szerint: „Kodály Zoltán tanár úr már az 50-ben készült könyvnél is hangsúlyozta, hogy pentaton gyerekdalokat alkalmazzunk, és azokat keressük össze. A Magyar Népzene Tára első kötete (kb. 1200 gyermekdal) csak egy „tár”, egy tudományosan összeválogatott adathalmaz, egy „lomtár”, egy raktár, tehát nemcsak jól választott dalok vannak benne, hanem minden." (Forrai, 1973, p. 25-30). Így az abból átvett dalanyagot még további játékválogatással kellett kiegészíteni, Kodály Zoltán instrukcióit figyelembe véve. A könyvbe a magyar népi dalanyag mellé értékes kortárs költők és zeneszerzők tollából kikerült művek is szerepeltek, valamint más népek (orosz, szlovák, lengyel, bolgár) magyarra fordított dalai, szintén igényes szövegfordításokkal.

Forrai Katalin lankadatlanul fejlesztette, alakította módszertani elképzelését és az óvodások ideális énekes zenei anyagát. Ebben segíthette, hogy munkássága szinte a kezdetektől három pilléren állt: a saját zeneóvodai foglalkozásai mellett részt vett az óvónőképzésben, illetve képzésekkel, előadásokkal, bemutató foglalkozásokkal és publikációkkal segítette a pályán lévő óvónőket. 1957-ben Kerecsényi László, Diener Klára és Varga Ilona közreműködésével újabb módszertani segédkönyvet publikált Ének-zene az óvodában címmel. Ez a munka 6 kiadást ért meg. Kodály Zoltán az 1957-ben kibővítetten kiadott Zene az ovodában írásában (Kodály, 1957, p. 44) erre a munkára „kitűnő segédkönyv"-ként tesz említést. Az 1957-es, Ének-zene az óvodában módszertani kézikönyv már teljes mértékig a kodályi reformprogramra épült mind módszertanilag, mind a zenei anyag szempontjából. Dalanyagát szinte teljes mértékben magyar népi gyermekdalok alkották, illetve kisebb részben magyar zeneszerzők magyar népi gyermekdalszerű komponált dalai. A zenei anyagot ebben a munkában is életkorokra bontottan közölték, és minden korosztálynak külön-külön válogattak, ajánlottak mondókát, népi dalos játékot játékleírásokkal, illetve zenehallgatási anyagot. A kor oktatásmódszertani elvárásának megfelelően megjelölték a kötelezően vagy ajánlottan elsajátítandó ismeretanyagot. Komoly módszertani alapossággal, korszerü leírásokkal segítették a segédanyag alkalmazását. Talán ez a kézikönyv inspirálhatta Kodály 
Zoltánt arra, hogy 1962-ben kiadja az óvodás korosztálynak szánt, saját szerzeményeket tartalmazó gyüjteményét Kis emberek dalai címen. Ebben a legkisebbek számára gyüjtötte egybe a 333 olvasógyakorlatának magyar költők tollából született értékes szövegekkel ellátott darabjait.

A 20. század 70-es éveire Magyarországon csökkent az ideologizálásra irányuló központi törekvés, formálódott a gyermekekről alkotott kép is. A „politizáló gyermekből” iskolára készülő gyermek lett. Az óvodapedagógiában fokozatosan erősödött az óvodáknak azon funkciója, hogy a gyermekvédelmet és az iskola-előkészítést hatékonyan támogassák. Az oktatáspolitikai döntéseket mindinkább a tudományos kutatások eredményeire alapozva hozták meg. Ez hívta életre az 1971-es Óvodai Nevelés Programját, amit 1985-ig többször is kiadtak változatlan tartalommal. Ennek a programnak kidolgozásában oroszlánrészt vállalt Forrai Katalin az Országos Pedagógiai Intézet munkatársaként, ahol 1959 óta dolgozott. E keretjellegű program kidolgozása késztethette őt arra, hogy ismét újragondolja módszertanát és az ahhoz kapcsolódó zenei gyüjteményét. 1974-ben, immár teljes mértékben önállóan, saját koncepció szerint összeállított könyvét adták ki Ének az óvodában címen. Ennek a könyvnek a bővített, átdolgozott kiadása kerül minden leendő óvodapedagógus kezébe a mai napig, és lesz első szakmódszertani támasza, amikor megkezdi pályáját. Az óvodások ének-zenei nevelésének sokszínű világában értékálló könyvnek bizonyul Forrai Katalin munkája, azonban természetesnek vesszük tartalmát, üzenetét, és nem mélyedünk el benne kellő alapossággal. Talán elő is fordul ebből adódóan, hogy félremagyarázzuk, félreértjük, pontatlanul közvetítjük könyvének egyes gondolatait. Vajon ismerjük-e a könyv módszertani részét olyan részletekbe menően, hogy utána Forrai Katalinhoz hasonló pontossággal átgondolt ének-zene foglalkozásokat tarthassunk? Vagy a mintegy 320 mondókát és dalt tartalmazó gyüjteményének minden darabját mélyrehatóan elsajátítottuk-e annyira, hogy abból folyamatosan frissülő, bővülő repertoárral támogassuk óvodásaink zenei fejlődését és ne csupán a legközismertebb darabjait ismerjük, ismételjük?

\section{Kodály Zoltán koncepciójának megjelenése Forrai Katalin módszertanában}

Kodály Zoltánnak az óvodai ének-zenei neveléssel kapcsolatos első nyilvános felszólalása a Magyar Énekoktatók Országos Egyesületében az 1941-ben tartott (fent említett) beszéde volt. Az előadás írott változata később a Zenei Szemle hasábjain jelent meg1943-ban. Kodály így emlékszik vissza: „Keresve, hol kell és lehet tenni valamit, mind kisebbekhez jutottam, végre elérkeztem az ovodáig." (Kodály, 1951, idézi Bónis, 1982, p. 247). Az akkorra már nagy tekintélyư Kodály Zoltán kritikája fordulatot hozott az óvodák zenepedagógiai elképzelésében, hiszen Kodály kemény szavakkal bírálta a németes, magyartalan, művészietlen óvodai tananyagot, melyben gyakori volt a hazafias, erkölcsi tartalmú, vagy egyéb tudástartalmat hordozó tandal, esztétikai értéket 
nem hordozó, mesterkélt dallammal ellátott magyar népi gyermekdal (Sándor, 1964). Kodály tisztázta, hogy az óvodai nevelés szerepe pótolhatatlan, amit ebben a korban elmulasztanak, később helyre nem hozható. Úgy vélte, hogy mint ahogy egy épület sem áll meg megfelelő alap nélkül, úgy a zenei müveltség sem képzelhető el megfelelő kisgyermekkori képzés nélkül, hiszen „magyarságunk tudatalatti elemei" csak így épülhetnek be a személyiségbe. Kodály szerint a kultúrát nem lehet átvenni, örökölni, hanem újra kell tanulni minden nemzedéknek. (Kodály, 1944, idézi Bónis, 1982, p. 156). Ennek érdekében a gyermekeknek csakis tiszta forrásból származó, az életkori sajátosságaiknak megfelelő magyar népi gyermekdalokat szabad tanítani a mesterkélt, didaktikus dalok helyett. Így fogalmazott: „A gyermek fogékony korát ki kell használni, mert az ebben a korban szerzett benyomások életre szólóak maradnak." - idézte fel Forrai Katalin (Forrai, 1978, p. 13). Erre a gondolatra Kodály egy későbbi beszédében is visszatér: „Kezdeni már az óvodában kell, mert ott a gyermek játszva megtanulja azt, amit az elemiben már késő." (Kodály, 1941, idézi Bónis , 1982, p. 93-94) „Nagy tömeg zenei benyomást raktároz el a gyermek már az iskola előtt, s ha ebben túlteng a rossz, akkor zenei sorsa már eldőlt egész életére." (Kodály, 1951, idézi Bónis,1982, p. 246).

Kodály a zenei nevelés hozadékaként - nem csupán az óvodáskorúakra vonatkozóan - azt látta, hogy a zene lélekre, személyiségre gyakorolt hatása révén a pedagógia kiemelkedően hatékony eszköze lehet. „A zenével nemcsak zenét tanulunk. Az ének felszabadít, bátorít, gátlásokból, félénkségből kigyógyít. Koncentrál, testi-lelki diszpozíción javít, munkára kedvet csinál, alkalmasabbá tesz, figyelemre-fegyelemre szoktat." (Kodály, 1974, idézi Bónis, 1982, I. p. 304). Kodály meglátása a zene fontosságáról az óvodák iskola-előkészítő szerepéhez is jól illeszkedett: „A zene elemei külön-külön is értékes nevelő eszközök. A ritmus figyelmet, koncentrációt, határozottságot, beidegző képességet fejleszt. A dallam az érzés világát nyitja meg. Az erőfokok változása, a hangszín: hallószervünk élesítője. Az ének végül oly sokoldalú testi működés, hogy testnevelő hatása is felmérhetetlen, - ha tán valakinek a léleknevelés nem volna fontos." (Kodály, 1941, p. 10). Az élményt adó zenei nevelés az iskola előkészítője, a kottaíráshoz- és olvasáshoz szükséges képességek megalapozója, de ennél is fontosabb, hogy a zenéhez, énekléshez füződő attitűd megalapozója: „Az óvóban [...] történik az első alapvetés, az első, elhatározó zenei élmények gyüjtése. Amit itt tanul a gyermek, sohasem tudja elfelejteni: vérévé válik." (Kodály, 1941, p. 9). Kodály a gyermekdalok alapozó szerepét alapvetőnek gondolta az óvodai nevelésben, hiszen olyan jelentősége van, mint az anyanyelvnek. „A tudatalatti nemzeti vonások legjobb megalapozója a néphagyomány, elsősorban játék- és gyermekdalaival." (Kodály, 1941. p. 11). Minden nemzet a saját népzenéjén keresztül ismerheti meg népét, abból építheti identitását. A hagyomány átörökítése, a tradíció átadása igen fontos a jövő nemzedékének formálódása szempontjából. A hagyományt, illetve amit a hagyományból értéknek tartunk, meg kell tanítani. Igy adhatjuk át a tényleges kultúrát, értékrendet. A népi gyermekdalok a leg- 
egyszerűbbek és egyúttal a legértékesebbek. „A tudatalatti magyarság első talpköve a nyelv, [...] a másik talpköve a zene. Óvodában talán még fontosabb a nyelvnél is. Nem az értelemhez szól elsősorban, bár értelemfejlesztő oldala is nagy érték." (Kodály, 1957, p. 10).

Kodály pedagógiai elképzelésének másik alappillére az éneklés szerepe, az éneklés jelentősége. Ahogy Ő fogalmaz: „Mélyebb zenei műveltség mindig csak ott fejlődött, ahol ének volt az alapja." (Kodály, 1941, idézi Bónis, 1982, p. 117) „A hangszer nélküli szabad ének a zenei képességek igazi és mélyreható iskolája." (Kodály, 1946, idézi Bónis, 1982, . 199). Az éneklés aktivitás, cselekvő jelenlét a zenében, melyre mindenki képes, és ami közelebb visz a zene megértéséhez, megismeréséhez. Az éneklés a hangszerjáték alapja is, mert általa halljuk azt a zenei folyamatot magunkban, amit a hangszerünkön megszólaltatunk. Ha alaposan megismerjük a zenei anyagot, megértjük, reprodukáljuk, akkor majd a magunk kedvére építkezünk, alkotunk belőle. Az óvodások zenei nevelése során ezért törekedni kell, hogy egyszerü, világos, számukra könnyen átvehető, értelmezhető formákat ismerjenek meg a gyerekek, például a motivikusan építkező népi gyermekdalokat, és ezeken belül a kisebb zenei egységeken belül vegyék észre az eltéréseket és azonosságokat. A gyerekeket a kérdés-felelet és a zenei variábilitás világába a letisztult formájú gyermekdalokon keresztül vezethetjük be és tapasztalataik nyomán ösztönözhetjük őket rögtönzésre. „A gyermekjáték mindennél mélyebb betekintést enged a népzene őskorába. Mozdulattal, cselekménnyel egybekötött ének sokkal ősibb és egyben bonyolultabb jelenség, mint az egyszerü dal." (Kodály, 1951, XII.). Ugyanakkor az óvodások számára éppen ezért megfelelő. A mozgásélmény, az együttesség öröme, a játékélmény életkori igényüket elégíti ki. „A zene kezdetben ne is legyen más mint játék, amire a gyermekek maguktól vállalkoznak, bármiféle ösztönzés vagy biztatás nélkül.” (Kodály, 1964, idézi Bónis, 1982,, p. 204). „[...] nagy e játékok tisztán emberi értéke is: fokozzák a társas érzést, életörömet. A mai gyermek koravénsége ellen nincs jobb orvosság." (Kodály, 1937, idézi Bónis , 1982, I. p. 63). Kodály és Forrai Katalin is állítja, hogy a népi dalosjáték a gyermek természetes nyelve, és benne mozgással kísérten élheti át ősidők közösségformáló játékait. Kodály így fogalmazott: „A gyermek ösztönszerű, természetes nyelve a dal, s minél fiatalabb, annál inkább kívánja mellé a mozgást. [...] A zene és a testmozgás szerves kapcsolata: az énekes játék a szabad ég alatt - ősidők óta a gyermek életének legfőbb öröme. Ez ősi játékok fenntartása elsőrendű kulturális és nemzeti érdek. Aki nem játszotta gyermekkorában a játékokat, annyival is kevésbé magyar." (Kodály, 1937, idézi Bónis, 1982, p. 62).

\section{Forrai Katalin három módszertani könyvének összehasonlító elemzése}

Forrai Katalinnak nagy szerepe volt Magyarországon az óvodások énekeszenei nevelését érintő megfelelő módszertani irány megtalálásában. Kodály elképzelései alapvetően az elemi/alapfokú iskolákra vonatkoztak. Kodály 
ikonikus alakjának kezdetben az Éneklő Ifjúság mozgalom (1934), majd az ének-zenei tagozatos iskolák (első: Kecskemét, 1950) létrejöttének kapcsán volt óriási jelentősége. Ezen reformtörekvések szele érintette meg az óvodai nevelést az énekes-zenei nevelés céljaira, feladataira vonatkozóan. Már 1939ben a kisgyermeknevelőknek szóló folyóiratokban (például Kisdednevelés, Magyar Gyermeknevelés) utalnak cikkek arra, hogy az óvoda köteles megfelelő előkészítést nyújtani Kodály törekvéseinek kibontakozása érdekében. A cikkek alapján érezhető, hogy Kodály gondolatai, zenei anyagra vonatkozó javaslatai lassan formálni kezdték az óvodák zenei világát. Forrai Katalin kitartó munkája, Kodállyal való együtt gondolkodása, jó pedagógusi személyisége révén megtalálta a helyes utat az óvodáskorúak zenei neveléséhez. Több évtizeden keresztül kereste a számukra kitűzhető optimális célokat, optimális elvárásokat, figyelte nem zenei és zenei képességeik fejlődését, hogy mindinkább finomíthassa módszertanát, és rájuk szabhassa zenei gyüjteményeit. Már az 1951-es Óvodai énektanítás címen kiadott gyűjteményes módszertani könyvben és az 1957-es Ének-zene az óvodában módszertani könyvben a szerzők között szerepelt. Így jól követhető, hogy 1951 és 1957 között is több változás látható módszertani elképzelésében. Koncepciója mind érzékenyebb lett az óvodáskorú gyermekekre, így mind nagyobb hangsúlyt kapott a játékosság, a változatos mozgásvilág. Ez olvasható ki az 1951-es Óvodai énektanítás kapcsán, a Gyermeknevelés folyóiratban (1952) megjelent háromrészes Énekoktatás az óvodában című cikksorozatából, ahol a tervezés, a tervszerűség szükségessége mellett érvel, és olyan foglalkozások megtervezését sürgeti, ahol a nyugodt és élénk részek váltakoznak a gyermekek igényeihez igazodóan. Kiemeli azt is, hogy a dalok rögzítése, megtanítása sok ismételt eljátszás során valósuljon meg, és a gyerekek első sorban az együtt éneklés örömét éljék át.

Az 1974-es kiadású saját munkáját, az Ének az óvodában címen megjelent módszertani könyvét jelentősen más elképzelés mentén állította össze. Úgy vélte, hogy ha a pedagógus ismeri a gyermekkor természetes fejlődési szakaszait, ismeri a módot, ahogy az egyes életkorban fejlesztheti a gyermekek képességeit és ismeri az értékes, megfelelő zenei anyag kritériumait, akkor kezei között olyan gyermekek nevelődnek, akik szeretnek énekelni és szívesen hallgatnak zenét. Forrai Katalin a gyerekek mellett az óvókat, az ő munkájukat is folyamatosan figyelte, és reagált igényeikre, illetve a korszerű pedagógiai nézetekhez is folyamatosan „hozzáformálta” elképzeléseit. Így jött létre egy olyan módszertani könyv, amelyben a több mint 100 oldalnyi elméleti tartalomhoz úgy kapcsolt 337 mondókát és dalt, hogy nem bontotta az óvodások életkorához igazodóan, nem kötötte meg, hogy mit kötelező vagy ajánlott megtanítani és mikor, hanem a zenei anyag alapos elemzését követően (hangkészlet, hangterjedelem, zenei forma, dallami nehézség), a gyermekek életkori sajátosságainak megfelelő hangfekvésben (lehetőleg D' és H’ abszolút hangok közé) lejegyezve adta közre. Az egyes hangkészleteken belül betürendben rendezte el a dalokat, hogy semmilyen módon ne befolyásolja az óvodapedagógusokat. Az volt a koncepciója, hogy minden felkészült pedagógus szabadon válogasson a 
jól strukturált gyűjteményből pedagógiai céljainak, koncepciójának megfelelően. Érdekes összehasonlítani ennek a könyvnek az átdolgozott kiadásait is, melyekben nem csupán a történelmi-politikai hatások nyomán tapasztalhatunk változásokat, hanem szakmai-pedagógiai szempontok mentén is. Ugyanis Forrai Katalin maga is "tesztelte” dalgyüjteményét, vagyis zeneóvodai foglalkozásain használta a dalokat, és figyelte a gyerekek közötti beválásukat, de szakfelügyelőként az országot járva az óvodapedagógusok között is megfigyelte, hogy mely dalok lettek kedveltek, vagy éppen mely dalok dallama nem tudott helyesen gyökeret verni. Ha megismerjük a koncepciót, amely mentén változtatott az egyes kiadások mondóka- és dalanyagán, közelebb juthatunk ahhoz, hogy mi magunk is érezzük, hogyan bővíthetjük saját zenei repertoárunkat.

\section{Az elemzésre kerülő könyvek bemutatása}

Három olyan, óvodások zenei neveléséhez kapcsolódó módszertani könyvet hasonlítok össze, melyek Forrai Katalin nevéhez, illetve munkájához köthetők. Ezek a könyvek az 1951-ben, a közoktatásügyi miniszter rendeletére, a Tankönyvkiadó által megjelent Óvodai énektanitás, az 1957-ben, szintén a Tankönyvkiadónál megjelent Ének-zene az óvodában, és az 1974-ben, a Zenemükiadónál megjelent Ének az óvodában módszertani segédanyag.

Az 1951-es könyvet Barát Istvánnével és Oláh Zsuzsannával írták, az 1957-ben kiadott könyvet Diener Klárával, Kerecsényi Lászlóval és Vargha Ilonával. Az 1974-ben megjelent Ének az óvodában könyv teljes egészében saját munkája. Forrai Katalin pályájának alakulásáról tudjuk többek között, hogy 1951-1959 között a budapesti Brunszvik Teréz Óvónőképzőn tanított, 1959-től az Országos Pedagógiai Intézet főmunkatársaként dolgozott, és az 1971-ben megjelent Az óvodai nevelés programja címü alapdokumentum ének-zenei neveléssel kapcsolatos szakértője volt.

A következőkben tekintsük át, hogy milyen formai és tartalmi változásokon mentek át a fent említett módszertani könyvek.

\section{1. táblázat}

Az elemzésre kerülö módszertani könyvek tartalmának arányait bemutató táblázat

\begin{tabular}{|l|c|c|c|c|}
\hline & $\begin{array}{c}\text { Terjedelem } \\
\text { oldalszámban }\end{array}$ & \multicolumn{2}{|c|}{$\begin{array}{c}\text { A módszertani rész oldalszáma } \\
\text { és aránya a teljes tartalomra } \\
\text { vetítetten }\end{array}$} & $\begin{array}{c}\text { A gyủjtemé- } \\
\text { nyes rész sze- } \\
\text { melvényeinek } \\
\text { száma }\end{array}$ \\
\hline $\begin{array}{l}\text { Óvodai énektaní- } \\
\text { tás (ÓÉT) }\end{array}$ & 144 & 33 & $23 \%$ & 232 \\
\hline $\begin{array}{l}\text { Ének-zene az óvo- } \\
\text { dában (ÉZÓ) }\end{array}$ & 239 & 67 & $67 \%$ & 277 \\
\hline $\begin{array}{l}\text { Ének az óvodában } \\
\text { (ÉÓ) }\end{array}$ & 339 & 127 & $37,5 \%$ & 337 \\
\hline
\end{tabular}




\section{Az Óvodai énektanitás (1951) címü könyv elemzö bemutatása}

Az összehasonlító elemzést időrendben teszem meg, így az első bemutatásra, elemzésre kerülő könyv az Óvodai énektanítás címen megjelent könyvnek már a címe is utal arra, hogy az 50-es évek elején az óvodákban hangsúlyosan oktatni, tanítani akarták a gyermekeket. Erőteljesen érvényesült az óvoda iskolaelőkészítő szerepe, amelyhez egy erőteljes didaktikusság társult, kötelezően szervezett órákkal. Az óvoda feladatát Forrai Katalin és munkatársai abban látták, hogy a gyermekek értelmi képességeinek megfelelő élményeket adjon, s közben kifejlessze képességeiket, felkeltse érdeklődésüket, a zene iránti szeretetüket, vagyis megadja a gyermekek zenei nevelésének alapját (ÓÉT, 1951, p. 4). Módszertannal kapcsolatos gondolataikat nyolc nagy témakörbe rendezetten fejtették ki:

- Az óvodai énektanítás jelentösége címen írnak a zenei nevelés céljairól, feladatairól, kifejti az éneklés teljes személyiségre (értelmi, érzelmi, szellemi területekre) gyakorolt hatásait, közösség- és szemléletformáló erejét, valamint az óvodai énektanítás zenei anyagának tagozódását. A zenei anyaggal kapcsolatosan már itt megjegyezhetjük, hogy öt csoportba osztják a közölt szemelvényeket: népi gyermek- és játékdalok; a Szovjetunió és a népi demokráciák gyermekdalai; a szocialista öntudat kifejlesztését szolgáló dalok (munkáról, termelésről, ünnepekről); ritmusképzésre és hallásfejlesztésre alkalmas dalok; zenehallgatásra szánt dalok. Vagyis ebből látszik, hogy a zenei anyag erőteljesen alárendelődik a politikai identitástudat alakításának, valamint a fejlesztési, oktatási céloknak (lásd a 2. táblázatot). A zenei gyüjtemény szemelvényei a három óvodai korcsoportra tagoltan vannak elrendezve (kiscsoportosoknak /3-4 évesek/, középsősöknek /4-5 évesek/, nagycsoportosoknak /5-6 évesek/), azon belül (1) ritmusképzésre, járásra (menetelésre) alkalmas énekek; (2) játékhoz, szereplők kiválasztására megfelelő énekes játékok; (3) dalok, amik zenei képességfejlesztésre, identitástudat formálására, ünnepekre, ünnepélyekre alkalmasak. Külön fejezetben gyűjtötték ki a meseszerü dalokat, valamint a meghallgatásra szánt dalokat, melyek orosz és a népi demokráciák gyermekdalai, illetve hangszeres müzenék.

\section{2. táblázat}

Az Óvodai énektanítás könyv zenei gyüjteményének arányait szemléltető táblázat

\begin{tabular}{|l|c|c|c|c|c|}
\hline & \multicolumn{2}{|c|}{$\begin{array}{c}\text { Óvodai korcsoportokra bontott } \\
\text { számosságok } \\
\text { (kis-, középsö-, nagycsoport) }\end{array}$} & $\begin{array}{c}\text { A teljes anyagra vonat- } \\
\text { kozó számosságok és } \\
\text { arányszámok }\end{array}$ \\
\hline $\begin{array}{l}\text { Járásra (menetelésre) } \\
\text { alkalmas zenei anyag }\end{array}$ & 8 & 13 & 14 & 35 & $\sim 15,08 \%$ \\
\hline $\begin{array}{l}\text { Énekes játékok, kiol- } \\
\text { vasók }\end{array}$ & 18 & 22 & 23 & 63 & $\sim 27,15 \%$ \\
\hline
\end{tabular}




\begin{tabular}{|l|l|l|l|l|l|}
\hline Dalok & 21 & 28 & 39 & 88 & $\sim 37,93 \%$ \\
\hline Mesék & & & & 14 & $\sim 6,03 \%$ \\
\hline Zenehallgatási anyag & & & & 32 & $\sim 13,79 \%$ \\
\hline
\end{tabular}

- A könyv második nagy témaköre, a gyermek zenei fejlödése, ahol az óvodás kor előtti zenei nevelésről és az óvodás kor három korcsoportjának fejlődéséről írnak. Kiemelik Kodály Zoltán 1941-es Zene az óvodában tanulmányának gondolatát: „Nem szabad a kicsinyek lelkébe zenei gyomot ültetni, vagyis zenei nevelésünket odáig kell mélyíteni, hogy megkülönböztessék a gyomot a nemes növénytől.” (ÓÉT, 1951, p. 6). A korcsoportok fokról fokra fejlesztését ritmusképzés - későbbi könyvekben ritmusérzék-fejlesztésként találkozunk majd ezzel a fogalommal -, éneklési képesség és hallásfejlesztés terén bontják ki. Hangsúlyozzák, hogy cél az, hogy a gyermekek szeressenek énekelni, szépen tudjanak énekelni, az egyéb zenei képességterületeken szerzett tudás pedig előkészítse őket az iskolai énektanításra és alapot adjon a további zenei képzéshez. Ami szembetűnő, hogy főképp a nagycsoportosok esetében igen nagy menynyiségű dalismeretről, 50-60 dalról írnak (óvodás kor végére 80-100 dal ismeretéről), s ezek lehetséges hangterjedelmére oktávnyi távolságot írnak. A későbbi módszertani könyvekben az óvodáskorúak ideális hangterjedelmére vonatkozóan inkább a szext (hat hang) távolságot látjuk majd preferáltnak.

- A Zenei nevelés szempontjai címü fejezetben térnek ki részletesen az egyes fejlesztési területeket célzó módszerekre, eljárásokra. A ritmusérzék fejlesztésének kapcsán alapvető eljárásként írnak a meneteltetésről, akár éneklés nélkül is, például hangszerjátékra, dobszóra, illetve vezényszavakat javasolnak az egyöntetű mozgások elé. Az iskolai ritmusképzést ritmusírással és ritmusolvasással készítik elő a 'tá' és 'titi' ritmusértékeket jelölő szótagok megnevezésével. A meneteléshez, „díszlépésekhez", ritmustapsoláshoz ajánlott dalok között sok a nagy hangterjedelmü, bonyolult dallamvezetésü dal.

Ebben a könyvben a hallásfejlesztés gondolatkörébe tartozik a tiszta éneklési képesség és a zenehallgatóvá nevelés is. Az alfejezetekben a hallásfejlesztéshez kapcsolódóan térnek ki a dalanyag helyes kiválasztására, amit a gyüjteményben nehezedő sorrendbe rendeztek, és ajánlják is a sorrend betartását. Felhívják a figyelmet arra, hogy a tömegdalok hangterjedelme, ritmusvilága, szövege nem felel meg az óvodások életkorának, mégis a dalanyagot lapozva látjuk, hogy számos nagy hangterjedelmü, bonyolult dallamvonalú, nehéznek tekinthető dalt közölnek, főleg a nagycsoportosok számára. 


\section{3. táblázat}

Az Óvodai énektanitás könyv zenei anyagának életkori sajátosságokhoz illeszkedése

\begin{tabular}{|l|l|l|l|}
\hline \multicolumn{1}{|c|}{$\begin{array}{c}\text { Életkornak } \\
\text { megfelelö }\end{array}$} & \multicolumn{1}{|c|}{ kiscsoport } & \multicolumn{1}{|c|}{ középső csoport } & \multicolumn{1}{c|}{ nagycsoport } \\
\hline Hangkészlet & $\begin{array}{l}70,2 \% \\
4-5 \text { hang }\end{array}$ & $\begin{array}{l}76,2 \% \\
5-6 \text { hang }\end{array}$ & $\begin{array}{l}59,2 \% \\
\text { az oktávot lehetőleg } \\
\text { nem érintő }\end{array}$ \\
\hline Dallamvezetés & $59,6 \%$ & $49,2 \%$ & $13,2 \%$ \\
\hline Ritmika & $\begin{array}{l}95,7 \% \\
\text { negyedek és nyol- } \\
\text { cadok }\end{array}$ & $\begin{array}{l}82,5 \% \\
\text { szinkópa is }\end{array}$ & $\begin{array}{l}69,7 \% \\
\text { tizenhatod, éles és } \\
\text { nyújtott ritmus is }\end{array}$ \\
\hline $\begin{array}{l}\text { Hangterjedelem és } \\
\text { hangfekvés }\end{array}$ & $\begin{array}{l}78,7 \% \\
\text { D'-H' hangok kö- } \\
\text { zött, de T5-nél nem } \\
\text { nagyobb hangterje- } \\
\text { delemmel }\end{array}$ & $\begin{array}{l}\text { 50,8\% } \\
\text { D'-H' hangok kö- } \\
\text { zött, legfeljebb szext } \\
\text { hangterjedelemmel }\end{array}$ & $\begin{array}{l}\text { 46\% } \\
\text { C'-C" hangok között, } \\
\text { szext terjedelemmel, } \\
\text { helyenként esetleg } \\
\text { oktáv érintéssel }\end{array}$ \\
\hline
\end{tabular}

A hallásfejlesztés és tiszta éneklés, biztos intonáció kapcsán az óvodások között is alkalmazzák a kodályi relatív szolmizációt, hangoztatják kézjelhez, kottához kapcsoltan a szolmizációs szótagokat (pentaton hangkészletben: lá szó mi ré dó). Mesébe ágyazottan tanítják, gyakoroltatják ezeknek az elnevezéseknek, elvont fogalmaknak a megértését. A belső hallás fejlesztése szisztematikus, sok ma is alkalmazott eljárással támogatott, például dalfelismerés dúdolásról vagy dallambújtatás - ahol a dal egy-egy szakaszát a gyermekek magukban éneklik, és így fejlődik belső hallásuk. Erre a gyakoroltatási módra (dallambújtatás) a mai gyakorlatban is több, fokozatosan nehezedő feladat él. A zenehallgatás céljaként azt jelölik meg, hogy az óvodások pár perc erejéig tudjanak elmélyedni az óvónő hangszeres játékában, énekében, így váljanak zenekedvelő, zeneélvező hallgatósággá. Módszertanilag itt még megengedőbb szemlélettel találkozunk, a gyermekek ekkor is szabadon bekapcsolódhatnak az éneklésbe, vagy kaphatnak feladatot az óvónő zenéléséhez. Később jobban elvárássá válik, hogy csak passzív élvezői legyenek az óvónői pár perces előadásnak, az átélés ne éneklésben nyilvánuljon meg, hiszen ekkor olyan nehézségű zenei anyag kerül elő, amelynek az éneklése technikai problémát okoz nekik, megerőltethetik hangszálukat, nem tudják igényesen, tisztán elénekelni a dalt, így a hamis, igénytelen énekléshez szoknának.

- Az Általános tudnivalók című fejezetben a tervezésből kiindulva ejtenek szót az ekkor még órának - később foglalkozásnak vagy tevékenységnek - nevezett alkalmak típusairól, felépítéséről, a hangképzés órákon kívüli hallásfejlesztés lehetőségeiről. Az „énekórákra” heti kétszer 20-40 percben került sor, a középső és nagycsoportosoknál minden foglalkozásra javasolják egy újabb dal megtanítását. Ma is helyes, korszerű pedagógiai érveket 
hoznak a tervezés, vázlatírás szükségessége mellett. A foglalkozásokat két részből építik fel, egy mozgalmasabb és egy nyugodtabb részből, amelyek sorrendje nem kötött. A mozgalmas részbe „ritmusképzést” szolgáló meneteltetést, vonulást, illetve énekes játékokat javasolnak, a nyugodt foglalkozás részbe leginkább ülő helyzetben megvalósuló zenei képességfejlesztést, elméleti tudásátadást, ritmushangszereken játszó gyerekekből zenekari élménynyújtást, zenehallgatást, mesehallgatást. Amit a mai pedagógiai szemszögből nézve kiemelnék még, hogy ekkor még az új dal megtanítását követően azt azonnal fejlesztésre, zenei elemek gyakorlására használták. Ezt ma már nem tartjuk célszerűnek friss, nem kellően rögzült zenei anyagon. Fontosabbnak tartjuk az élmény jelentőségét, az új dalhoz történő pozitív attitűd kialakulását. Azonban egy másik, többször hangsúlyozott módszertani elvárást Forrai Katalinék könyvéből követendő példaként kiemelném, hogy az elsajátított dalok, énekes játékok éneklésekor engedni kell a gyermekeket minél önállóbban énekelni, minél önfeledtebben játszani, és e közben ne felejtsünk el meggyőződni arról, hogy elsajátították-e, tisztán éneklik-e a megtanított dalokat.

- A Zenei nevelés helye a szocialista óvodai nevelésben fejezet lényegében azt hangsúlyozza, hogy az énekes, zenei nevelés jól kapcsolható más nevelési területekhez, úgy mint a testi, értelmi, erkölcsi, esztétikai neveléshez. Ezek a nevelői hatás koncentrációját, egységességét, komplexitását szolgáló gondolatok alapvetőek ma is, másként értelmezve.

- Az Óvodai ünnepek és ünnepélyek téma érintése nem csupán politikai szempontból, és az 50-es években fontos téma. A gyerekek szerepeltetése, annak szükségessége, pozitív és negatív hozadékainak felmérése ma is pedagógiai kérdéseket vet fel. A könyvben arról írnak, hogy a szereplés, ünnepség esetén a csoport felkészítésének szisztémáját, a müsor életkorhoz igazítottságát alaposan át kell gondolnia az óvónőnek.

- Ebben a hetedik fejezetben Az óvodai énektanitás anyagáról és a korcsoportok szerinti menetéről írnak. Szisztematikusan végig viszik minden korosztály kapcsán a (I.) ritmusérzék fejlesztését mozgással összekapcsoltan és ritmushangszerek használatával, (II.) a hallásfejlesztést az alábbi területek érintésével: hangszínfelismerés, dallamfelismerés, dallambújtatás, dallam-visszaéneklés, kézjellel támogatott dallaméneklés, hangmagasság megkülönböztetés, illetve a helyes légzésmódot, hangerőt, hangképzést segítő éneklési képesség. Végül éves tanmenetre példát adó táblázatokban szemléltetve, bemutatják az egyes korcsoportok számára ideálisnak gondolt dalanyagot, énekes játékokat szeptember és május hónapok között. A vegyes korosztályú csoportok vonatkozásában azt javasolják, hogy a ritmusérzék fejlesztésénél csoportbontásban gondolkozva adjanak különböző nehézségű feladatot a gyermekeknek, a hallásfejlesztő lehetőségek és az énekes játékok, dallamok közül pedig inkább a kis-középsős korcsoportnak valókat tanítsák. Ezekben a csoportokban nem javasolják a ritmusjelek írását és a szolmizálást. 
- A módszertani rész zárásaként két-két komplett foglalkozásvázlatot közölnek minden korosztály számára.

A szaknyelv tekintetében már érintettem egy-egy olyan fogalmat, amelyet ma már nem használunk óvodai ének-zenei nevelés kapcsán. Ilyen az énekóra, tanítás, ritmusképzés, vagy olyan módszereket, eljárásokat, amelyek ma már nem korszerűek, például vezényszavak, ritmusírás, ritmusolvasás, ritmusra járás (ami feltehetően az egyenletes járásra utalhatott), kézjelezés, szolmizálás. Vannak olyan fogalmak, amiket ekkor még nem használtak, például a motívum (a gyermekdalok legkisebb szerkezeti egysége), lüktetés, ritmusérzék-fejlesztés, zenehallgatóvá nevelés.

\section{Az Ének-zene az óvodában (1957) címü könyv elemzö bemutatása}

Az következő módszertani könyv az 1957-ben kiadott Ének-zene az óvodában. Ennek pedagógiai felfogására hatással lehetett a század közepén, a háború után újjászervezett óvodák munkáját meghatározó, 1953-ban született törvény, s az azt követően megjelent Óvodai foglalkozások kiadvány. Az óvodák az 1953-as törvény szerint mint közoktatási intézmények készítik elő az iskolai oktatást, ehhez adott módszertani támpontokat a Módszertani Levelek címen kiadott dokumentum. A Módszertani Levelek alapvetően a kötelező foglalkozásokról szólt, amiken keresztül valósultak meg a nevelés általános céljai, akárcsak egy iskolai órán. Didaktikai értéke volt ennek a dokumentumnak, hogy a fokozatosságot tartotta szem előtt. A magyar óvodapedagógiai gyakorlatot meghatározó következő dokumentum 1957-ben látott napvilágot kézikönyv formájában, Nevelőmunka az óvodában címen. Ebben központilag elfogadott irányelveket fektettek le az óvodai nevelés szocialista pedagógiai tartalmára vonatkozóan. Új és előremutató eleme volt a dokumentumnak, hogy elvárta az óvónőktől, hogy az óvodai élet „tudatos irányításakor" a 3-6 éves kor sajátosságait és szükségleteit vegyék figyelembe, szemléltető eszközökkel és korszerű eljárásokkal biztosítsák a gyermekek sokoldalú fejlődését. Felismerték a ,játék különös jelentőségét” a kötelező foglalkozások megtartása mellett. „Abban az óvodában, ahol sokat játszanak, nyugodt, fegyelmezett légkör uralkodik, a kötelező foglalkozásokon a gyermekek figyelme hatványozottabb." (Nevelőmunka az óvodában, 1957, p. 58). A Kézikönyv tanterv-jellegü volt. Pontosan megadta azokat a tartalmakat, amelyeket minden óvodában fel kellett dolgozni. Forrai Katalinék könyve ehhez a központi szabályozáshoz illeszkedett, és kívánta segíteni az óvónők munkáját.

A módszertani alapvetéseket tartalmazó fejezetek 67 oldalon, öt témakörbe vannak elrendezve. A bevezetésben célként itt is a zenei érdeklődés felkeltését és a zene megszerettetését jelölik meg, kiemelve az életkornak megfelelő zenei anyagot. Kodályi elvek mentén jelölik ki a zenei anyagot, utalva az 1951-ben, a Magyar Tudományos Akadémia kiadásában megjelent 
Magyar Népzene Tára I., Gyermekjáték kötetére. A módszertanhoz kapcsolódó gyưjtemény zenei anyagáról annyit írnak előre vetítetten, hogy magyar gyermekdalok, mondókák; népzenei szellemben fogant, a szocializmus értékeit hirdető művészi igényű dalocskák; valamint más népek dalai teszik ki.

\section{4. táblázat}

Az Ének-zene az óvodában könyv zenei anyagának eloszlását mutató táblázat

\begin{tabular}{|l|c|c|c|c|}
\hline & $\begin{array}{c}\text { kiscso- } \\
\text { port }\end{array}$ & $\begin{array}{c}\text { középső } \\
\text { csoport }\end{array}$ & $\begin{array}{c}\text { nagy- } \\
\text { csoport }\end{array}$ & összesen \\
\hline Magyar mondókák, kiolvasók & 13 & 17 & 16 & 46 \\
\hline Magyar népi dalos játékok & 25 & 49 & 51 & 125 \\
\hline Zenehallgatásra szánt anyag & 14 & 18 & 20 & 52 \\
\hline
\end{tabular}

A rövid bevezető után a szerzők rögtön rátérnek a konkrét módszertani kérdéskörökre:

- A Zenei nevelés két ága fejezeten belül (1.) a ritmusképzésre és (2.) a hallásfejlesztésre. A korábbi módszertani könyvtől abban különbözik, hogy sokkal rendszerezettebben, részletesebben tárgyalják az egyes fejlesztési irányokat, képekkel is gazdagon szemléltetve. Például a mozgással történő ritmusérzék fejlesztésnél külön írnak a játékos mozdulatokról, mozgásformákról, az egyenletes járásról, tapsolásról, a taps és járás összekapcsolásáról, a gyermektánc szerepéről, és kiemelten felhívják a figyelmet a magyar népi mondókák ritmusérzék-fejlesztésben betöltött szerepére.

Többször is hangsúlyozzák, hogy az óvónő alapozzon a gyerekek ötleteire, fantáziájára, és mindig tartsa szem előtt az életkori sajátosságokat, ne kívánjon mesterkélt, túlzó, nehéz mozdulatokat, mozgásformákat. Itt már használják a motívum kifejezést a mondókák, gyermekdalok formavilágának bemutatásakor.

Módszertanilag - a korábbiakkal ellentétben - forszírozzák a dalok cselekményét megjelenítő játékos, ütemes (lüktető) mozdulatokat, elutasítják az éneklés, zene nélküli, vezényszóval indított vagy dobbal vezetett öncélú meneteltetést. Kihangsúlyozzák, hogy a változatos, játékos gyakoroltatás élményt ad a gyermekek számára. Ebben a könyvben sokkal több gyakorlati tanácsot, módszertani fogást írnak le a fokozatosság jegyében, mint korábban. A monoton gyakoroltatás feloldására a tér bejárására is több variánst közölnek rajzokkal illusztrálva. A ritmusírás, ritmusolvasás teljes egészében elmarad már ebben a könyvben.

A hallásfejlesztés területe alá sorolják továbbra is az éneklési képesség fejlesztését, itt már tiszta éneklés fejlesztéseként említve, és elsőként, vagyis hangsúlyos helyen feldolgozva a témakörön belül. Ehhez kapcsolódóan erőteljesen hangsúlyozzák az óvodások életkorának megfelelő ideális hangmagasságot, hangterjedelmet, dallami nehézséget. A gyüjteményt életkorokra bontottan, azon belül is nehezedő zenei anyaggal 
állították össze, megjelölve benne a kötelezően megtanítandó dalokat, de azon felül is a gyüjtemény szigorú követését hangsúlyozzák. A tiszta éneklésről szóló alfejezetet követi a hangerő és hangszín, a helyes éneklés, a belső hallás, és a zenehallgatás témaköre.

Az óvónő módszertani tudatosságát konkrét példákkal segítik, minden apró részletre ráirányítják figyelmét, és módszertani fogásokat adnak a kezébe. Például hogyan javítson, miben legyen következetes, mikor adódhat nehézség, azt hogyan küszöbölje ki, mikor lesz világos a gyermekek számára a szemléltetés, mivel teheti változatosabbá a foglalkozásait, vagy éppen hogyan legyen példaértékű. A korábbi zenei fejlesztési fogások besorolása úgy alakul, hogy a tiszta éneklésnél említik a magasabb-mélyebb érzékeltetését akár a különböző lágéban éneklés kapcsán, akár a kezdőhang átvételekor, akár a nehezebb dallamfordulatok, hangközugrások kigyakorlása kapcsán. A hangszín, hangerő megkülönböztetése, felismerése kapcsán az éneklésből indulnak ki, a saját élményü tapasztalatszerzés jelentőségéből, de a hangszerek használatáról is szót ejtenek. A belső hallás, zenei emlékezőképesség gyakorlatai között szerepel továbbra is a dallamfelismerés, halkabb-hangosabb éneklés, dallambújtatás. Már nem javasolják a kézjelről énekeltetést, a szolmizálást mint a dallam leképezését segítő módszert.

A zenehallgatást a zene figyelésére szoktatásként értelmezik. Így írnak: „Élvezze a bemutatott zenei szemelvények szépségét, hangulatát akkor is, ha ő maga nem énekel." (ÉZÓ, 1957, p. 35.). A foglalkozások felépítésében a zenehallgatás helyeként a záró szakaszt jelölik meg, és felcserélhetőnek tartják ritmushangszeres gyerekzenekarral, illetve elhagyhatónak írják, amennyiben új zenei anyagot tanítottak, és azt ismétlik át a gyerekekkel a foglalkozás végén. A zenehallgatásos anyagból elmaradnak a szolmizációs nevek köré épülő mesék, és a meseszerü dalok sem kerülnek külön kiemelésre. A zenei gyüjtemény úgy van összeállítva, hogy korcsoportonként ajánlanak zenehallgatásra alkalmas dalokat, zeneműveket. (lásd 4. táblázat)

- A zenei nevelés módszertana fejezeten belül külön fejezetet szánnak arra, hogy a tervszerüség és játékosság szellemében írjanak a foglalkozásokra történő felkészülésről. A foglalkozások felépítését, és annak mentén történő besorolását külön alfejezetekben taglalják. Beszélnek ismétlő, feldolgozó foglalkozásról, mozgás/játék nélküli új dal megtanítását, illetve énekes játék megtanítását célzó foglalkozásról. Itt térnek ki az új dal megtanításának módszertani elveire is. Ebben a fejezetben korcsoportonként 3-3 vázlatmintán keresztül is bemutatják annak módját. A több korosztályt magában foglaló csoportokról (osztatlan csoportról) is írnak, és segítik az ilyen csoportokban dolgozó óvónők munkáját. Ez azért is fontos, mert a zenei gyüjtemény kötött dalanyaga nem ad számukra egyértelmű előírást. Kimondatlanul, de differenciálás megvalósításáról írnak, amikor az osztatlan csoportban dolgozó óvónőknek leírják, hogy 
mit figyeljenek meg a csoportjukon, hogyan szabják az életkori összetétel alapján rájuk a zenei fejlesztést. Ugyanakkor javasolják, hogy a heti két alkalomból az egyiken legyen együtt a csoport, a másikon a nagyok fejlesztésére fókuszáljanak.

A tervezés kapcsán kiderül a könyvből, hogy a kiscsoportosoknak heti egy 10-15 perces foglalkozás kötelező, a nagyobbaknak heti kettő. A középsősöknek 15-20 perces, nagyoknak 20-30 perces hosszúságú „énekóra" van előírva. A foglalkozások felépítése három részre válik a korábbi kettő helyett:bevezető rész, amely ráhangolódást, előkészítést céloz, fó rész, ahol megvalósul a fejlesztés vagy daltanítás, több énekes játék eljátszása, és befejező rész, amely levezetést, elcsöndesedést szolgál, ebben a részben énekelhet, zenélhet az óvónő, vagy átismételtetheti az új zenei anyagot, vagy élményt adó közös zenélést, dramatizálást szervezhet. A foglalkozásokon minden alkalommal van ritmusérzék fejlesztését és hallásfejlesztést célzó rész, új zenei anyagot pedig minden második alkalomra javasolnak, hasonlóan a zenehallgatáshoz. Egy foglalkozásba átlagosan 4-6 dal beépítését javasolják. Az énekes játékokat mindig mozgással, játékkal együtt kell tanítani, soha nem választva le a szöveget, ritmust a dallamról. A bonyolultabb, hosszabb énekes játékoknál megengedőleg írják, hogy lehet egyszerủbben tanítani, vagy több játékszakaszra bontottan. Az új zenei anyagon ebben a könyvben már nem engedik meg a zenei fejlesztést, ezt így indokolják: „Új dalt ne alkalmazzunk hangképzéshez, egyéb hallásfejlesztéshez, mert ez megbontja a dallam és szöveg ekkor még bizonytalan egységét." (ÉZÓ, 1957, p. 43.). A frissen tanult anyag foglalkozás zárásakénti átismétlését azért javasolják, hogy pontosan rögzüljön a dallam a gyerekekben, mert a rosszul rögzülőt nehéz lesz később javítani.

- A hangszerekrôl szóló fejezetet a gyermekeknek adható, a fejlesztést szolgáló ritmushangszerekről írnak először, módszertani szempontból jelentősen nem eltérően az 1951-es könyvtől. Az óvónő hangszerei, hangszerhasználata kapcsán ismét több módszertani fogást, megfontolandó ötletet írnak, mint korábban, több hangszerről (furulya, zongora, hegedü, gitár, facimbalom, xilofon) is leírják, hogy mikor, mire, hogyan alkalmazható.

- A könyv az ötödik fejezetben ér el a dalanyag ismertetéséhez, kiválasztásának szempontjaihoz. Itt is hangsúlyozza a magyar népi mondókák jelentőségét, a nagyobbak esetében a kiolvasó mondókák szerepét. Mindhárom korcsoport zenei anyaga nagyobbrészt magyar népi dalos játék, ezeket egészíti ki a zenehallgatásra szánt zenei anyag. (4. táblázat)

A Gyüjteményben külön kiemelik a köszöntőket, ünnepi dalokat más népek gyermekdalait (54 szemelvény). Ezek között is van 13 magyar népdal, 11 komponált gyermekdal. Ezeken túl 9, a szocializmus értékeit hirdető dal, 8, más népek dala, valamint 8 , alkalmakhoz, ünnepekhez illeszthető dal. Ezeknek a függelékben szereplő daloknak a zöme olyan dallam, ami 
megfelelő arra, hogy megtanulják, énekeljék a középsős vagy nagycsoportos óvodások. A dalgyűjtemény első részében minden korcsoportnak nehezedő rendben rendezetten közölték a zenei anyagot. A dalválasztás szempontjai, nehézségének, életkorhoz illesztésének szempontjai között említik az formai egyszerüséget és tökéletességet, a hangkészletet, a ritmikai és dallamvezetésbeli nehézséget, bonyolultságot, illetve a játékforma bonyolultságát. A záró alfejezetet olyan, a mindennapi gyakorlatban használatos dalok megemlítésével, elemzésével zárják, melyek nem ideálisak az óvodáskorúak zenei nevelésére. Ezek a német eredetű mü- vagy tandalok ismertetőjegyeit hordozzák. Úgy látják a szerzők, hogy nem segítheti e dallamok terjedését az óvónő. Ahhoz, hogy felismerjék ezeket az óvónők, kottapéldákkal, konkrét dalokon szemléltetik sajátosságaikat, például a hármashangzatszerü dallamvezetést, a szekvenciákat mutató dallamvezetéseket, a rossz prozódiát, a németes jellegü dallamvezetéseket.

- Általános tudnivalókkal záródik a könyv módszertani része. Ebben a szabadban megvalósítható énekes lehetőségekről és az óvodai ünnepélyek életkorhoz igazításáról írnak.

\section{Az Ének az óvodában (1974) címü könyv elemzö bemutatása}

A harmadik elemzett könyv, az 1974-es Ének az óvodában könyv amellett, hogy Forrai Katalin saját, önálló könyve, a legletisztultabb struktúrájú, legterjedelmesebb, és legkövetkezetesebben átgondolt és végigvezetett könyv a módszertani tartalma és a hozzá illesztett gyüjtemény tekintetében egyaránt. A könyv előzménye, hogy Forrai Katalin ekkor már 15 éve az Országos Pedagógiai Intézet munkatársa, ebből kifolyólag szakmailag elismert, aktív résztvevője az országosan müködő felügyeleti rendszernek. Fel tudta mérni a korábbi módszertani segédanyagok beválását, alkalmazhatóságát. Jól ismerte a gyakorlatban jelentkező bizonytalanságokat, nehézségeket, a rosszul értelmezett módszertani elveket, a gyakran előforduló olyan zenei anyagokat, amelyek nem voltak ideálisak az óvodáskorúak zenei nevelésére.

Az Országos Pedagógiai Intézet munkatársaként jelentős szerepe volt az 1971-ben megjelent alapdokumentum kidolgozásában, Az óvodai nevelés programjában, mely két évtizeden keresztül meghatározta az óvodai nevelés tartalmát. Ez a nevelési Program útmutatást adott a szocialista nevelés megvalósításához, az óvodások céltudatos neveléséhez, a hatékony gyakorlati óvodákban folyó munkához, többek között az egyéni bánásmódra irányuló törekvések megvalósíthatóságához. A Program a 3-6 éves gyermekek sokoldalú, harmonikus fejlődését kívánta elősegíteni. Rámutatott, hogy az óvoda a családdal együtt készítheti fel eredményesen az iskolára a gyermeket.

A pedagógiai koncepció azon alapult, hogy a játék az óvodás korú gyermek elsődleges tevékenysége, és ehhez nélkülözhetetlen a nyugodt légkör, az elegendő játékidő, a megfelelő hely kialakítása, és a játékszerek. Az oktatás az óvónő és a gyermek kölcsönösen egymásra ható tevékenysége, és a ta- 
nulás szempontjából fontos az érzelmi ráhangolás. Két szervezeti formában gondolkozik a Program a tanítás kapcsán, ezek a kötelező foglalkozások és a tervszerü, de kötetlen foglalkozások.

Ezek az elvek tökéletesen tükröződnek Forrai Katalin módszertani segédanyagában. 127 oldalon, négy fejezetben rendezi el a könyv módszertani tartalmát. Ennek a könyvrésznek, amely 37,5\%-át teszi ki a könyvnek, különösen nagy a jelentősége, mert a Program az óvónőknek módszertani szabadságot adott, sőt elvárta tőlük, hogy megtalálják a csoportjukban hatásos, változatos módszereket, és ezzel örömteli, élményszerű tanulást biztosítsanak a gyermekeknek. Kimondhatjuk, hogy az előző könyvhöz (1957) képest nem a módszertani alapelvekben, fejlesztési célokban, tartalmakban volt változás, hanem abban, hogy hogyan valósítsák meg a zenei nevelést.

A zenei nevelés az esztétikai nevelés egyik pillére lett a Programban. Az éneklés, a zenei nevelés emberformáló erejét, ízlésre, szépérzékre hatását már Kodály Zoltán is hirdette, így ez nem volt újszerü aspektusa a zenei nevelés besorolásának. A fejlődést mozgató erőt a gyermekek aktív, cselekvő jelenlétében, szabad felfedező kedvük kiaknázásában, érzelmi alapú fogékonyságuk felébresztésében látta a Program, amely keretszerüen írta elő például a kötelező foglalkozásokat, a fejlesztés minimumát és maximumát, az óvónők feladatait, a követelményeket, ugyanakkor a módszerek, fejlesztési anyagok tekintetében nem írt elő.

Forrai Katalin az Ének az óvodában módszertani könyvének I. fejezetében, amelynek $A$ zenei nevelés helye az óvodai nevelés folyamatában címet adta, ezeket a fentebbi alapelveket veszi sorra az ének-zenei nevelés szempontjából, kitérve a gyermekek óvoda előtti és óvoda utáni zenei fejlődésére is. A II. fejezetben tér ki $A z$ óvodai ének-zenei nevelés anyagára. A könyv a korábbiaktól abban különbözik, hogy csupán elsajátításra, megtanításra szánt zenei anyag szerepel a könyv zenei gyüjteményében. Magyar népi mondókák, magyar gyermekdalok, énekes játékok, magyar költők népi dallamra született értékes művei.

Forrai Katalin úgy segíti az óvónők életkorokhoz megfelelő dal és énekes játék választását, hogy a gyüjtemény dalait több típusú tárgymutatóba rendezi. A zenei szemelvényeket „bemutatja” a tárgymutatóban zenei rend szerint; hangkészletek szerint elrendezetten, mellette játékmegjelöléssel; és külön játékrend és szövegtartalom szerint is. Így az óvónők mind a nehezedő hangkészlet, hangterjedelem, mind a nehezedő játékmód, mind az év rendjéhez, alkalmaihoz igazítottan tudnak válogatni, keresni a zenei anyagban. Ebben a gyüjteményben nincs a felnőttek zenei világából származó népdal, nincsen más népek dala és müzenei szemelvény sem.

Magában a gyűjteményben 60 mondókát, 180 énekes játékot közöl betűrendbe rendezetten, a dalokat bővülő hangkészletenként tagoltan. (Szó mi biton daloktól indulva, szó mi dó triton, lá szó mi trichord majd lá szó mi dó tetraton hangkészletek felé haladva.) A zenei gyüitemény harmadik nagy részében alkalmi énekek, ünnepekhez illeszthető, főként komponált dalok szerepelnek. 
Ez a 97 dal mind olyan hangterjedelmü, amelyet óvodások is énekelhetnek. A teljes gyüjteményben szisztematikusan olyan hangfekvésben adja közre a dalokat, hogy azok leginkább megfeleljenek az óvodáskorúaknak, vagyis dó pentaton rendszerbe illeszkedő, szó vagy lá hangot is tartalmazó dalokat $\mathrm{D}$ alaphangon; a dó-ré-mi hangkészletűeket $\mathrm{F}$ alaphangon; a dó hexachord dalokat is D alaphangon; a lá pentaton rendszerbe illeszkedő dallamokat alapvetően D alaphangon; de azokat, ahol az alsó szó hang is szerepel, azokat $\mathrm{E}$ alaphangon.

\section{5. táblázat}

Az Ének az óvodában könyv zenei anyagának eloszlása müfaj és hangterjedelem szempontjából

\begin{tabular}{|l|c|c|c|c|c|}
\hline & Összesen & $\begin{array}{c}\text { Legfeljebb } \\
\text { tercnyi } \\
\text { hangterje- } \\
\text { delem }\end{array}$ & $\begin{array}{c}\text { Tercnél na- } \\
\text { gyobb, de } \\
\text { legfeljebb } \\
\text { kvint hang- } \\
\text { terjedelem }\end{array}$ & $\begin{array}{c}\text { Kvintnél } \\
\text { nagyobb, de } \\
\text { legfeljebb } \\
\text { szext hang- } \\
\text { terjedelem }\end{array}$ & $\begin{array}{c}\text { Szextnél } \\
\text { nagyobb, de } \\
\text { legfeljebb } \\
\text { szeptim } \\
\text { hangterje- } \\
\text { delem }\end{array}$ \\
\hline $\begin{array}{l}\text { Magyar } \\
\text { énekes } \\
\text { játék, gyer- } \\
\text { mekdal }\end{array}$ & 180 & 59 & 56 & 65 & 0 \\
\hline $\begin{array}{l}\text { Gyermek- } \\
\text { dal költött } \\
\text { szöveggel }\end{array}$ & 3 & 0 & 1 & 2 & 0 \\
\hline $\begin{array}{l}\text { Komponált } \\
\text { gyermekdal }\end{array}$ & 86 & 4 & 30 & 51 & 1 \\
\hline $\begin{array}{l}\text { Népdal } \\
\text { költött } \\
\text { szöveggel }\end{array}$ & 8 & 0 & 2 & 5 & 1 \\
\hline
\end{tabular}

Forrai Katalin nem jelöl ki kötelezően megtanítandó anyagot, de az elméleti részben táblázatokban jelzi számossággal a minimum és maximum megtanítandó anyagot (Forrai, 1974, p. 34). A könyv elméleti részében még ebben a könyvben is szán egy fejezetet az óvodákban élő nemkívánatos daloknak. A III. nagy fejezet $A z$ óvodai ének-zenei nevelés módszerei címet kapta. Ebben szisztematikusan veszi sorra az irányelveket, az életkorokra vonatkozó fejlesztés elveit, a nevelés tervszerű és alkalomszerü formáit, végül az egyes képességfejlesztési területeket. Itt kap először azonos hangsúlyt az éneklési képesség fejlesztése, a ritmusérzék-, és a hallás fejlesztése mellett. Itt kiválik a fejlesztési területek közül a zenehallgatás, és mint élménynyújtási lehetőség kap szerepet.

Forrai Katalin külön fejezetet szentel a korszerü pedagógia szellemében a szemléltetés módszereinek, és a tervezésnek. Ebben a könyvben is szán egy fejezetet a foglalkozás felépítésének, de már csak néhány vázlatos, nem elő- 
író értelemben vett foglalkozást közöl, hogy ne érezzék korlátozva magukat az óvónők.

A korábbi könyvekben megismert módszerek visszaköszönnek, azonban rendre kiemeli, hogy engedjen szabad utat az óvónő a gyerekek ötleteinek, alkotó fantáziájuknak, alkalmazzon szemléltető eszközöket (bábot, kártyákat, hangszereket), legyen minél változatosabb a foglalkozás a játékokhoz kapcsolódó mozgásformákban, játékmódokban, akár saját ötleteket is felhasználva, és találjon ki változatos játékos feladatokat egy-egy foglalkozásra, mert a gyermekek a játék, a felszabadult utánzás, a rendszeres gyakorlás útján tanulnak. Ezen az elven nyugszik az a módszertani elképzelése, hogy a foglalkozások 70\%-át az énekes játékok tegyék ki.

A fejlesztésről tehát eltolódik a hangsúly a játékra, bár ugyanolyan didaktikusan fel kell építeni az éves tervet, vagy a foglalkozásokat, mint korábban, mert az óvónő feladata a gyerekek érdeklődésének ébren tartása, a jó hangulatú játékokhoz kapcsolódó, tapasztalatszerzésen alapuló ismeretátadás. Ehhez ismerni kell a gyermekek fejlettségi szintjét, teljesítőképességét, azt a szintet, amire el kívánjuk juttatni őket, illetve a nevelési és oktatási anyagot. Elvként így fogalmazott: „Közlő, ismétlő szövegek helyett cselekedni, a játékokat élni, a dalokat énekelni kell." (Forrai, 1974, p. 38). Az énekfoglalkozások a középső és nagycsoportokban kötelezőek, a kiscsoportosok számára tervszerüen előkészített kötetlen foglalkozásban kell gondolkozni. Több fejezetben is hangsúlyozza, hogy a zenei képességek fejlesztése, az énekes-zenei alkalmak nem korlátozódhatnak a kötött, kötelezően előírt foglalkozásokra. Az óvónő a nap során bármikor szabadon, alkalomszerủen játszhat, ismételhet a gyerekekkel.

A foglalkozások felépítése kapcsán Forrai megmarad a hármas tagoltságnál, hangsúlyozva, hogy egy kiemelt feladat köré kell felépíteni azokat, a bevezető rész a kiemelt fejlesztési feladat előkészítését szolgálja, a ráhangolódást; a fő rész az ismeretszerzésnek és a gyakorlásnak a helye; a befejező rész ad lehetőséget a gyermekek számára az élményt adó zenehallgatásra, közös zenélésre, bábozásra, dramatizálásra, vagy az újonnan tanult dalok, énekes játékok átismétlésére. Két foglalkozástípust említ, az új dalt tanító és az ismétlő foglalkozásformát. Ezekre hoz példát a könyv 116-124 oldalain. Érdekes, hogy a könyv elméleti részét A család és óvodák kapcsolatáról szóló IV. fejezettel zárja, így adva jelentőséget ennek a témának is.

Ez a módszerekben, eljárásokban, tartalomban kiteljesedett munka alapjaiban él tovább a mai napig Magyarországon. A változtatások, melyeket Forrai Katalin kezdeményezett az átdolgozott kiadásokban, így csoportosíthatók:

1. Történelmi-politikai szempontok:

a szocialista ideológiához illeszkedő, annak ünnepeihez kapcsolódó dalok, megzenésített versek beemelése, majd kivétele. Gondoljunk itt november 7-re (Nagy Októberi Szocialista Forradalom), március 21-re (Tanácsköztársaság kikiáltása), április 4-re („Hazánk felszabadulásának” ünnepe), május 1-re (Munka ünnepe). Ezekhez az ünnepekhez kapcsoló- 
dott többek között a Könnyü szél illatoz, Zim, zim, megy a gép, Süss, süss, napsugár dal.

2. Pedagógiai-szakmódszertani szempontok:

Például a játékmódok életkorhoz igazítása, vagy olyan típusú népi dalosjátékok keresése, amely megfelel az óvodás korú gyermekek testi, fizikai, szellemi, szociális fejlettségének. Vagy olyan dallamváltozatok, melyek hangkészlete, hangterjedelme, dallamvezetése alkalmas arra, hogy az óvodások tisztán, igényesen el tudják énekelni, vagyis fiziológiai képességeikhez (hangszálaik paramétereihez, tüdőkapacitásukhoz) igazodók legyenek, és az óvodapedagógusok is szívesen tanítsák azokat.

Ezen változások nyomon követhetőek, ha megfigyeljük, hogy a zenei anyag - például a hangkészlet alapján - egyre letisztultabb, egyre sokrétübben tagolt lett. A mozgásformák kapcsán például a keresztfogással haladás, a csípőfogással ugrálva haladás helyett kisgyermekekre méretezett mozgásformákat közöl, vagy kétféle játékvariációt ad egy-egy dalos játékhoz (például Kis, kis kígyó, Kocsit, kocsit). A korábbi módszertani könyvekben még meghatározó szerepet betöltő meneteltetést - akár zene nélküli dobszóra is - már didaktikusnak, öncélúnak gondolta, egyes dalokhoz, mondókákhoz kapcsolódóan jelezte.

Azokat a dalokat, amelyeknek dallama rosszul vagy egyáltalán nem vert gyökeret az óvodapedagógusok között, lecserélte. Amelyik komponált, kortárs zeneszerzőtől származó dal nem került be az óvók repertoárjába, azokon változtatást eszközölt költőnél vagy zeneszerzőnél (például Füzzünk lombot, Hova mégy). Gyüjteményes részéből több olyan dalos játék is kikerült, amihez hosszú párbeszédes rész kapcsolódott, vagy bonyolult játéka komolyabb szervezést igényelt a tevékenység során, és esetenként próbára tette a gyerekek figyelemkoncentrációját, türelmét, ugyanakkor tönkretette a lendületes, önfeledt játékot.

A könyv, kiadásainak történetében talán a legjelentősebb átdolgozáson az 1991-es évben ment át, akkor került az elméleti részbe egy plusz fejezet Mélykutiné Dietrich Helga közreműködésével a zenei alkotókészség fejlesztésének kapcsán és a kiemelt zenei anyagok miatt 330-ra módosult a gyüjteményes anyag szemelvényszáma. 2004-ig, Forrai Katalin haláláig hétszer nyomta újra változatlan formában az Editio Musica Budapest (EMB) Kiadó, majd 2013-ig további háromszor, a könyv 20. kiadásáig. 2016-ban a Móra Könyvkiadónál M. Dietrich Helga, Forrai Katalin tanítványának szakmai ellenőrzése nyomán jelent meg az átdolgozott, felújított kiadás..

\section{Konklúzió}

Forrai Katalin elkötelezetten, folyamatosan megújulni képes pedagógusként vetette meg Magyarországon az iskola előtti zenei nevelés alapjait Kodály Zoltán szellemiségében. A bemutatott, elemzett könyveken túl számos oktatóanyag, cikk, tanulmány kapcsolódik nevéhez, melyek elemző feldolgozása hozzájárulhatna módszertanának mélyebb megismeréséhez, megértéséhez, annak 
átörökítendő értékeinek felismeréséhez. Forrai Katalin azért is példaértékü lehet számunkra, mert amikor a világot járva bemutatta mintegy 20 országban zenepedagógiai szisztémáját, ahol csak megfordult, annak az országnak a saját zenei hagyományait felfedezve, a gyermekdalokat az adott ország/nép anyanyelvén elsajátítva adta át elképzelését. Nemzetközi elismertsége mellett azonban soha nem felejtette el, hogy küldetése van Magyarországon. Az itt bemutatott, elemzett munkái is bizonyítják, hogy sokat tett azért, hogy a magyar óvodai ének-zenei nevelés erős alapokon nyugodjék, és majd 50 évre biztosítsa az óvodapedagógusok számára az első, alapvető, nevelésüket segítő módszertant és zenei gyüjteményt tartalmazó Ének az óvodában címü könyvet.

\section{Irodalom}

1953. évi III. kisdedóvási törvény. http://jogszabalyfigyelo.hu/index.php?id=29nkin8

7bpx8m1 cex\&state $=20130701 \& \mathrm{menu}=$ view [2021. 08.30.]

Barát, I., Forrai, K. \& Oláh, Zs. (1951). Óvodai énektanítás (módszer és dalok). Tankönyvkiadó.

Bartók, B. \& Kodály, Z. (1951). A Magyar Népzene Tára I. - Gyermekjátékok. Magyar Tudományos Akadémia.

Bónis, F. (1979, Ed.). Így láttuk Kodályt. Zeneműkiadó.

Diener, K., Kerecsényi, L., Vargha, I. \& Vikárné Forrai, K. (1957). Ének-zene az óvodában. Tankönyvkiadó.

Forrai, K. (1974). Ének az óvodában. Zenemükiadó.

Forrai, K. (1973). Az ének-zene helye az óvodai nevelés programjában. In Tanulmányok 3. - Óvónók II. Nyári Akadémiája. Kecskeméti Óvóképző Intézet.

Forrai, K. (1978). Zeneóvoda - óvodai zene. Parlando, 20(3), 13-14. https:// mandadb.hu/dokumentum/832857/Parlando_1978_3_szm.pdf (2021.08.30.)

Földesi, K., Balogh, E., Szabó, E., Hermann, A. \& Szabó, F. (1957). Nevelőmunka az óvodában - Útmutatás óvónők számára/A Művelődésügyi Minisztérium rendeletére. Tankönyvkiadó Vállalat.

Kodály, Z. (1941). Zene az ovodában. Zenemükiadó.

Kodály, Z. (1957). Zene az ovodában. Zenemúkiadó.

Kodály, Z.(1982). Visszatekintés I., II., III. - Összegyüjtött írások, beszédek, nyilatkozatok., Zenemúkiadó Vállalat.

Mészáros, I. (1988). Óvodai zenei nevelésünk másfél évszázada. Közgazdasági és Jogi Könyvkiadó.

Sándor, F. (1964, Ed.). Zenei nevelés Magyarországon. Zenemúkiadó Vállalat. 


\section{Hegedüsné Tóth, Zs.}

\section{The development of the methodology of singing and music education in the kindergarten - An analytical introduction of Katalin Forrai's methodological books}

Katalin Forrai was a renowned figure of early childhood and preschool music education in Hungary and abroad. She began to work out her concept of singing and music education in the late 1940s. She played an important role in early childhood and preschool music education for almost sixty years. Her methodological book Ének az óvodában [Music in the Kindergarten] (first published in 1974) and Ének a bölcsődében [Music in the Crèche] (1986) are fundamental works even today. This article aims to introduce the era with a brief historical overview in which Katalin Forrai's methodological concept of the music education of kindergarten-age children began to develop and also show how it changed continuously due to various factors. Using the method of content analysis, the paper explores how the methodological books associated with Katalin Forrai changed in content and methodology: from Óvodai énektanítás (Teaching Singing in the Kindergarten, 1951) to Ének-zene az óvodában (Singing and Music in the Kindergarten, 1957) and Ének az óvodában (Singing in the Kindergarten), which was first published in 1974, followed by several editions. The analytical examination of the methodological works (co-) authored by Katalin Forrai clearly shows the significant political, pedagogical and methodological changes which influenced the music education of kindergarten-age children. All of the discussed books were important manuals for preschool educators in each given era. Their analysis can explore what music material the singing and music activities were built upon, how they were organised, which development areas were targeted, and what methods and tools were used to support musical development. The comparative content analysis can confirm that Katalin Forrai's music pedagogy concepts and their foundations are still of universal relevance and provide guidance. The findings can help us maintain our methodological achievements and renew preschool music education while preserving its values.

Keywords: singing and music education, methodology, preschool education, content analysis

Hegedüsné Tóth Zsuzsanna: https://orcid.org/0000-0001-8768-9477 